Some girls wear their boredom like a negligee, reading secondhand fading copies of Real Romance.

These ones are not so pretty. They don't look up at passing squads of rubber-necking Yanks and Leeds United supporters-men laughing to hide from their wives.

Tomorrow the tourists will be shown their quota of Van Goghs, get pissed on gin, inspect the house where Anne Frank hid from death, and empty their pockets for model windmills.

They will send home postcards of the Royal Palace and the sunlit houseboat of the American Bible Society, and say nothing of women who grin behind glass day after contemptuous day, banking on flesh.

\title{
Andrew Waterman on Rodney Pybus
}

As, reading around in contemporary verse, I find my open mind beginning to glaze over at about line eight of too many magazine poems, I crush qualms that this reaction may be unkind or unfair by recalling Randall Jarrell's austere standard:

A good poet is someone who manages, in a lifetime of standing out in thunderstorms, to be struck by lightning five or six times.

A salutary rigour. Still, the work of one's contemporaries does have its special dimension of interest eliciting a spirit of approach modified from that one brings to the literature of the established past. One is not sifting for masterpieces: the occasional really magnificent poem discovered-"Waking Early Sunday Morning," "The Old Fools," "Funeral Music"-is a gift to feel grateful for, not to be expected. One may reasonably hope for pleasurable and stimulating poems, and poets, meaningfully of an age if not for all time. But the special additional concern one brings to the reading of the new is a caring for the living growth-point in the present of the art whose past glories matter to one, a caring born of one's commitment to the established, and indeed attesting to it; the academic who doesn't read contemporary poetry and fiction-he "has no time," it's "not his field," he's too busy putting up bookshelves round the house, etc., etc.-should not be trusted on whatever literature he does profess to judge.

Poetry is of course legitimately as variable in methods and effects as its possible purposes and authors, and I have no prescriptive axe to grind. But I do have some general sense of what I look for, and try honestly to recognise if present, in a new poem. That, in Johnsonian terms, it should in some perceptible way enable me "better to enjoy life, or better to endure 
it." That it should effect some significant clarification of its proposed area of life, while being in itself an experience, beyond whatever it may contain of comments on experience. To expand this from the individual poem to a poet's work as a whole: I find that while the contemporary poets who draw my attention, whose books and poems I look out for, may differ in themes, manner, texture-R. S. Thomas, Philip Larkin, Geoffrey Hill, Fleur Adcock, Seamus Heaney, to specify a few, aren't much, or necessarily, "like" one another-they have in common the ability to create and articulate through their work habitable coherent imaginative and moral worlds, to which disparate experience is assimilated. As of course, in their various days and ways, have all the important writers of the past. It boils down to a matter of concepts, values, obsessions, vision, and possessing the means to give these expression: imaginative, linguistic and rhythmical vitality all collaborate whenever a poet achieves that pitch of definition and resonance readily recognisable as excellence, if more complex to explicate. Memorability, an associated quality, is another basic test of poetry. And I think Edward Thomas distinguished a crucial general truth when, in the course of considering John Clare, he wrote, before the first world war:

Poetry is and must always be apparently revolutionary if active, anarchic if passive.

This is no matter of an overtly radical stance at the political or social level: much superficially "committed" poetry simply shows a poet pandering to the assumed predilections of his audience. Paradoxically, the worst turn a poet can do his audience is to set out to give it what it wants, and thus imprison his writing within the average of current taste and fashion, and ensure that it perishes with them. However subversive or iconoclastic its postures, such poetry will no more disturb than a Christmas card verse. And poetry should disturb: not aggressively, but by bewildering or undermining the settled categories within which most people, most of the time, find it expedient to fit life to feel comfortable. True writing, like true reading, is among other things a solitary deed of courage.

I've tried to establish some context of general attitudes or hopes, within which I turn to Rodney Pybus' two poems, "Marketing" and "Anne Frank's House." Both are readable, comprehensible, workmanlike; felt to be written out of authentic impulse about meaningful subjects, discernibly crafted to mediate their ideas and values through described scenes and details. The values, which the poems do wear rather conspicuously, are seen to be humane, for victims and against exploiters, etc.; no one will accuse Pybus of being "anti-life," unless perhaps the "life" happens to belong to American tourists, German tourists, Leeds United supporters, or other obvious skittles for bowling at. 
But I run ahead of myself. If neither poem seems to me finally successful, each deserves the careful reading through which I must argue my case.

"Marketing" begins rather captivatingly:

In stately 17 th century houses that lean together above the water, graceful and various survivors ...

The controlled flow of the lines collaborates towards realising the relaxed elegance that is being described; the slight anthropomorphisation of the houses is intimated unforcedly. But of course this opening evocation of the languid historical picturesque is a stratagem to jolt the reader against the brute contemporary realism of what immediately follows:

... women in windows show what they have

to sell. Red and purple neon signals through the afternoon dusk, pointing men to the super-market whores.

The poem proceeds through some rather laboured equating of the whores' selling of their flesh to hungry customers with the sale of butchers' meat, and an Audenesque simile-'Some girls wear their boredom like a negligee" -and then falls altogether from presentation into rather trite assertion and comment as the focus shifts from the girls to their putative clients:

passing squads of rubber-necking Yanks and Leeds United supporters-men laughing to hide from their wives.

I don't see what this last clause means; however, Pybus' gist from here to the end of the poem is all too obvious: prostitutes good, tourists/clients bad. So facile a dichotomy can only be a sentimentalisation, but the poem, except in a final ambiguity uncertain in its effect that I will come to in a moment, doesn't open itself to more complex possibilities. These tourists are by definition stereotypes, for whom seeing "their quota of Van Goghs," getting "pissed on gin," and going to "inspect the house where Anne Frank hid / from death" has to be much of a muchness. "Quota," "pissed," "inspect": one objects not to the diction of poetry being loaded, but that here it is in a way automatically reductive of those to whom it is applied. Engaging in identical activities himself, the poet might prefer a different terminology. If, incidentally, there is any intention to the coincidence of phrasing between "hid from death" here, and the "hide from their wives" which has already puzzled me, its point escapes me: perhaps it is just a clumsy oversight.

We are also told that the tourists will send home postcards of the obvious scenic stuff, "and say nothing of the women who grin behind glass." Well, 
no, in most cases probably not: but Pybus' intimation of his own superior sensitivities smacks of complacency, unintentionally belies the humane commitment his poem professes. But then he is dealing not with real people, but with cut-out targets.

Significantly, as the poem's content modulates from evocation and presentation to reductive comment, so it deteriorates stylistically. The opening lines are vital and resonant. The presentation of the whores is more mechanically done: the flesh-as-meat analogy is an unoriginal conceit not here redeemed by vivacity of treatment; the reiteration of "sell" at the start of two lines is all too thumping; the irony of "reading second-hand fading copies of Real Romance" clichéd. The poetry's rhetoric has become crass. But readymade concepts do of course tend to find expression in perfunctory language, and the last half of the poem limps to a close that has for me no effect of inevitability. Indeed, when I reach "contemptuous day" in the last line, I am not sure whether I am to take the contempt as suffered by the women, or as something they inflict. Maybe the ambiguity is intended, the contempt mutual. But I suspect muddle: while Pybus probably means us to see the whores both as despised by society and as causers of unease to it, he has not satisfactorily resolved the strands in his poem compassionating them as victims, and exposing them as exploitative materialists.

Pybus' other poem, where he himself “inspects” Anne Frank's house, I find both more ambitious and less flawed than "Marketing," though its virtues and defects are comparable. His ability to present, when he trusts it, is evident in an evocative opening section, or in such finely imagined details as

the final departing hoot in the Amsterdam dawn from the Zyklon B Express, overloaded with its cargo of fading yellow stars.

Of its nature-for it is attempting recovery of another, and past, mind and experience-this is a more "imagined" poem than "Marketing," and this both allows Pybus' gifts more scope, and exposes their limitations. The growingup of Anne Frank is evoked with delicacy and restraint-but the poetry operates at a level of notation, does not achieve the compelling inwardness of creation possible to an imagination more powerfully gifted with "negative capability." In this poem too Pybus remains essentially a poet of observation and comment, of the external view. Moreover, on occasion his admirably-intentioned linguistic fidelity to "objective" unglamorousness betrays him into mere prosaic flatness: "a girl's sense of muffled security," "tender aspirations towards the impossible," or

A peculiar but not uncomfortable place to struggle with growing up. 
though this last may be tactically defended as a deliberately slack lead-in to the tautly resonant "Up to a point."

And then, in ten notably unresonant and abstract final lines, Pybus again resorts to generalised comment. I don't suggest the poem needs no such closing movement; only that, as done, it is flat. So that when we come to (of the present-day German tourists),

Their eyes are not eloquent. Nor do they speak.

the poetry has not persuaded us of either Pybus' receptivity to the former, or his interpretation of the latter.

I seem to have been rather harsh on two poems that are not impostures, do show some ability to handle significant themes with imaginative and technical control, and have their graphic or felicitous details. What worries me is that, while Pybus has some genuine talent for precise notation of observed or imagined phenomena, for the luminous presented detail, he seems unwilling to trust these to resonate meaning; and as he spells it out, and moves from realisation to comment, what emerge are received attitudes, banal moral perceptions, unworthy of the poems' own subtler moments. Prosaic language and inert rhythmical movement are symptomatic of the prosaicism of the insights. Moreover, in poetry that does rather wear on its sleeve a principled humane commitment, Pybus' condemnation of a sort of voyeurism in others, while he exempts himself on grounds of aesthetic and moral superiority, has an unfortunate air of glib self-approval. One is uncomfortably aware of the reductive treatment of other lives here.

This is symptomatic of a crucial limitation. In all really good poetry, there is a fruitful tension between the urge, which literature with its concrete and imaginative dimensions is more capable of realising than any form of expository discourse, to do justice to life's irreducible complexities, and the converse impulse to elicit pattern, meaning, significance. In Pybus, particularly in "Marketing," didacticism prevails all too easily, the tension is forfeited, its energies lapse, all topples into simplifying comment.

So finally I feel that his imagination here shirks experience rather than informing and illumining it; that this is a poetry without vital dynamic. Passably competent, more honourable than memorable, yet on scrutiny not wholly the former, Pybus' two poems offer neither originality of vision, nor any searching challenge to the comfortable assumptions that tame life into mere manageability. There are real qualities to redeem, but their emergence will be a measure of Pybus' capacity to purge his poetry of cliché and fustian. 


\section{Rodney Pybus Replies}

Well. After Andrew Waterman's cold shower, almost anything I say in reply is in danger of sounding like a squeal of aggrieved irritation against the hand on the tap. We're not in the points-scoring business, however, and I do have some comments to make in turn. Many of my remarks and objections will be of a more general nature than I would like, but I can't prove I haven't done something an attentive reader says I have, and vice versa. I can only try to exclude (and inevitably fail) personal bias.

To take up a criticism Waterman makes more than once: I see nothing wrong, in principle, with making one's values "conspicuous," i.e., absolutely plain. (Of course, it can be done well, and it can be done badly.) Waterman suggests by "rather conspicuously" that he doesn't like their conspicuousness, and by the "rather" patronising tone, that he himself is rather above that kind of thing. So be it. But I do think it's a somewhat crude distortion of "Marketing" to suggest that it is anti-life because he thinks the poem's only purpose is to set up tourists and knock them down. I don't think I have made a facile dichotomy between good whores and bad tourists/clients (while acknowledging that the gap between intention and execution may yawn as wide as ever). As Waterman half-sees-and therefore half-contradicts himself-the point is that both groups are exploiters and exploited, mutually feeding a greedy system. I agree that my outline of the tourists' behaviour may indicate stereotyping-my point was to express briefly that thousands of Amsterdam tourists do conform to this pattern, and are therefore self-reductive, pouring themselves into the tourist industry's moulds. Perhaps it would have been clearer had I made it plain that the streets I describe are part of the city's official tourist itinerary. That was my point in ". . . say nothing of the women who grin behind glass." If this came over as complacency, etc., that's my fault; I was trying to "knock down" two industries which in their own ways "bank on flesh," not the men and women used by them.

Specifically: "laboured" I suppose is a matter of opinion, but "Audenesque" is neither here nor there-is it dismissive, pejorative, comparative, illustrative, descriptive or what? "Men laughing to hide from their wives" was intended to convey the behaviour not only of men alone in groups, laughing in part to cover up feelings of guilt and/or embarrassment in a sad attempt at machismo, but also of men in groups with their wives, joking to conceal other attitudes. I did think that this meaning, or some of it, was not too hermetic.

"Anne Frank's House": all I can say, really, is that I disagree. I was quite deliberately not striving for something redolent of "negative capability" (if it's something one can strive for); the "fidelity to 'objective' unglamorousness" did seem to me the best way of approaching this poem. I have no ob- 
jections, in principle, to poems of statement, as Waterman seems to havethough he did say himself that "poetry is of course legitimately as variable in methods and effects as its possible purposes and authors."

I do not understand what Waterman means by calling the last ten lines "abstract," though unresonant they may be. (Perhaps I have tried too hard to give both poems the qualities of good prose ...) My point was that the house had no discernible effect on the German tourists-I don't see this as putting out received attitudes or banal moral perceptions.

Some final points: I am very dubious about any sentence that begins "in all really good poetry" (is Waterman familiar with Greek, Chinese and Swahili?), and he also seems to exclude didactic poetry from his own vision of what constitutes good or great poetry. Where does this leave Lucretius and Brecht, and much of Horace, Pope, and Vergil, for instance? I must say, too, that I think much of Waterman's criticism, in tone and treatment, tended to be reductive rather than constructive: why else spend so much more time on the weaker poem, and damn the merits he does find with faint praise ("passably competent")? I don't want to be ungrateful, however; it is salutary to have this kind of contact with a reader, and that's the great virtue of this exercise.

\section{The Old, Cast up on Lawns / Andrew Waterman}

The old, cast up on lawns in wicker chairs sit waiting for the sun to drop, humped shoulders towards a screen of trees, hands fiddling with crochet or book.

What should I say to them?

That I have been far out in passion, rain, and come back streaked with light? They turn patiently features rubbed, effaced, or scored deep by more tides than they remember, tokens of enough weather; not really distracted from the branches charring where gold sinks at the garden's end.

Outgrowths of themselves, they hobble in seeming out of habit merely propped on shapes long warped from, once tall in hailstorms, distance lanes' white heat. 